\title{
The chemical composition of runoff from Canada Glacier, Antarctica: implications for glacier hydrology during a cool summer
}

\author{
Martyn TRANTER, ${ }^{1}$ Andrew G. FOUNTAIN,${ }^{2}$ W. Berry LYONS, ${ }^{3}$ Thomas H. NYLEN, ${ }^{2}$ \\ Kathy A. WELCH ${ }^{3}$ \\ ${ }^{1}$ Bristol Glaciology Centre, School of Geographical Sciences, University of Bristol, University Road, Bristol BS8 1SS, UK \\ E-mail: M.Tranter@bristol.ac.uk \\ ${ }^{2}$ Departments of Geography and Geology, Portland State University, PO Box 751, Portland, OR 97207-0751, USA \\ ${ }^{3}$ Byrd Polar Research Center, The Ohio State University, 1090 Carmack Road, Columbus, OH 43210-1002, USA
}

\begin{abstract}
Variations in the chemical composition of subsurface runoff within Canada Glacier, Antarctica, are used to identify the main source waters, which are vertical surfaces, and melt from solarheated debris within channels, cryoconite holes and pools. The main flow paths are subsurface connections between cryoconite holes, pools and riffles. The latter may become partially disconnected during hard freeze. The chemical composition of runoff at the outlet of Canada Glacier during January 2000 was dominated by $\mathrm{Ca}^{2+}, \mathrm{HCO}_{3}{ }^{-}$and sea salt $\left(\mathrm{Na}^{+}\right.$and $\left.\mathrm{Cl}^{-}\right)$, and became depleted in sea-salt and non-sea-salt $\left(^{*}\right) \mathrm{SO}_{4}{ }^{2-}$ as the subsurface drainage system in a frozen pool-and-riffle system was flushed and the melting ice surface became depleted of overwinter dry deposited salts. Only during 2 days of hard freeze did sea salt and ${ }^{*} \mathrm{SO}_{4}{ }^{2-}$ increase in concentration together. Otherwise, sea salt and ${ }^{*} \mathrm{SO}_{4}{ }^{2-}$ declined while ${ }^{*} \mathrm{Ca}^{2+}$ and $\mathrm{HCO}_{3}{ }^{-}$increased. The latter ions are derived from the chemical weathering of sediment in frozen-topped pools, channels and cryoconite holes. It is inferred that the hydrochemical processes which occur in the vestigial, subsurface drainage system are the elution of ions from ice melt, dilution of these ions downstream by ice melt from vertical surfaces and the dissolution of dust, in subsurface pools, channels and/or cryoconite holes.
\end{abstract}

\section{INTRODUCTION}

Taylor Valley (Fig. 1), one of the three McMurdo Dry Valleys, has been the subject of interdisciplinary investigations into the associations and feedbacks between physical, chemical and biological processes (Moorhead and others, 1999). The Dry Valleys are the largest ice-free land mass in Antarctica (Fountain and others, 1998) and are extreme polar deserts. Average annual temperatures in Taylor Valley are -16 to $-21^{\circ} \mathrm{C}$ (Doran and others, 2002b), annual precipitation on the valley floor is $<100 \mathrm{~mm}$ w.e. (Fountain and others, 1998) and average annual wind speeds are $2-4 \mathrm{~m} \mathrm{~s}^{-1}$ (Doran and others, 2002b). Despite these harsh conditions, the valleys are colonized by consortia of microbes, microflora and microfauna (Priscu, 1998). The provision of meltwater from glaciers and nutrient (principally $\mathrm{N}$ and $\mathrm{P}$ ) from a variety of sources is key to the functioning of the fragile interconnected ecosystems contained within glaciers, soils, streams and ice-topped lakes (McKnight and others, 1999; Moorhead and others, 1999). The functioning of the ecosystem as a whole is sensitive to climatic variations, and polar magnification effects are evident, since relatively small changes in climatic regime produce relatively large changes in the functioning of some elements of the ecosystem (Doran and others, 2002a).

We present chemical runoff data collected from Canada Glacier, Taylor Valley (Fig. 1), in January 2000. This austral summer (December and January) was relatively cool, with an average temperature of $-4.6{ }^{\circ} \mathrm{C}$. Average DecemberFebruary temperatures have been declining at $\sim 1.2^{\circ} \mathrm{C}$ per decade from 1986 through 2000 (Doran and others, 2002b). Consequently, little runoff occurred. Our aim is to document the hydrochemical processes which occur in a vestigial, subsurface, drainage system, whose overall morphology is largely fashioned during warm years when melting is copious. These warm years occur approximately once in every decade.

\section{FIELD SITE}

Taylor Valley $\left(77^{\circ} 00^{\prime} \mathrm{S}, 162^{\circ} 52^{\prime} \mathrm{E}\right)$ trends east to west, spanning $34 \mathrm{~km}$ from the Ross Sea to Taylor Glacier, is

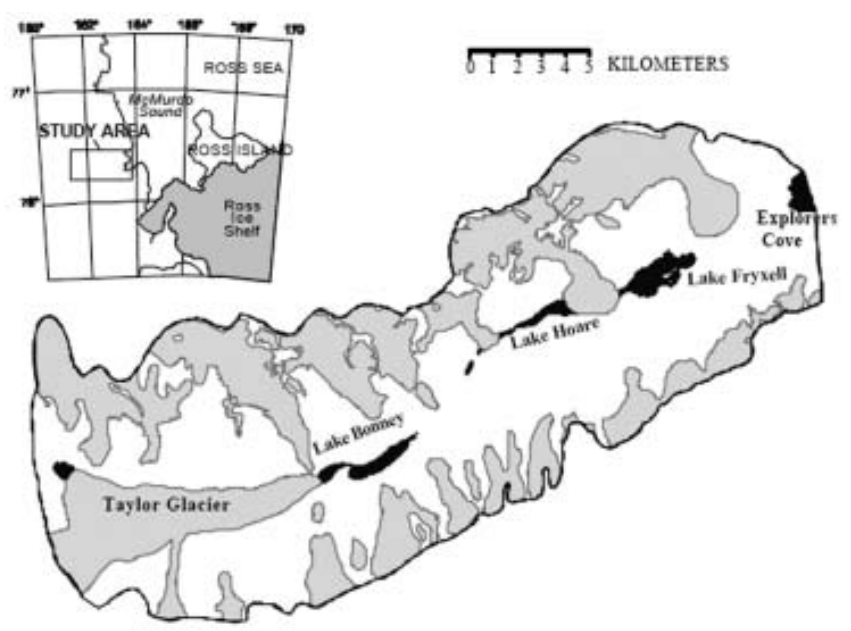

Fig. 1. Map of Taylor Valley. The grey features are glaciers, the black features are lakes and the white areas are soils and exposed bedrock. Note that Explorers Cove is an inlet of the Ross Sea. 


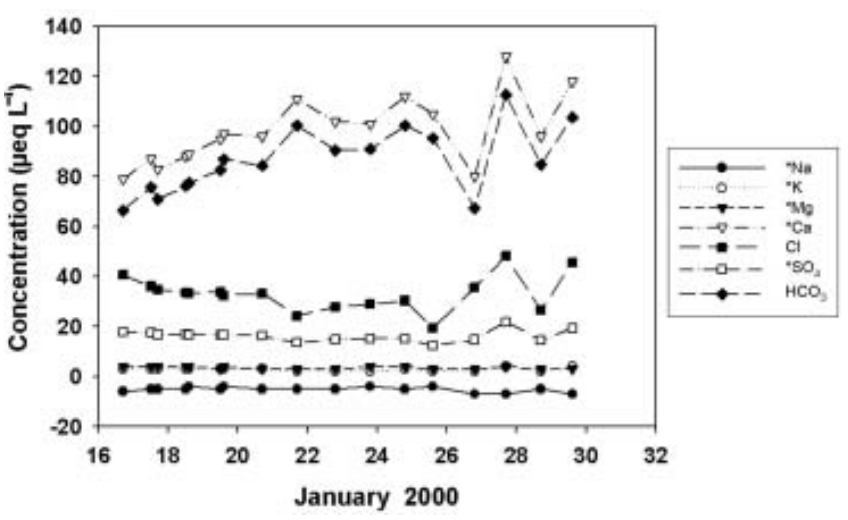

Fig. 2. The temporal variation in the concentration of major ions in the main outflow from Canada Glacier during January 2000. * denotes that ion concentrations are sea-salt corrected.

$\sim 400 \mathrm{~km}^{2}$ in area and is bound at its northern margin by the Asgard Range (Fig. 1). Katabatic winds blow from the East Antarctic ice sheet down Taylor Valley at speeds up to $\sim 40 \mathrm{~m} \mathrm{~s}^{-1}$, whereas milder summer winds blow from the Ross Sea toward the west (Doran and others, 2002b; Nylen and others, 2004).

Glaciers cover 35\% of Taylor Valley (Fountain and others, 1999). Canada Glacier, a cold-based alpine glacier, extends from the Asgard Range (Fig. 1) into Taylor Valley, with an ablation area of approximately $8.5 \mathrm{~km}^{2}$ (Lewis and others, 1999). The ablation zone of Canada Glacier faces south with a $3^{\circ}$ slope, is $3 \mathrm{~km}$ long and ranges in elevation from $100 \mathrm{~m}$ to the equilibrium line at $350 \mathrm{~m}$ (Lewis and others, 1999). Little melt was produced over the surface of the ablation zone during most summers of the 1990s, and terminus cliffs contributed up to $20 \%$ of runoff (Lewis and others, 1999). Supraglacial streams were rarely observed during the ten melt seasons prior to the warm summer of 2001/02 (Fortner and others, in press), when widespread melting of the surface occurred, producing a supraglacial drainage system similar to those found on cold-based Svalbard glaciers (Hodgkins and others, 1998). The surface of the lower ablation zone on Canada Glacier is composed of hills and swales, with their long dimension oriented parallel to the prevailing direction of katabatic winds. This topography presumably results, at least partially, from sediment transported to the glacier surface by katabatic winds, which subsequently melts into the ice. Higher concentrations of debris are found in the swales. Ice-covered meltwater channels are common on this glacier, and some streams cut across this topography following the average surface slope of the glacier. The streams form pool-and-riffle sequences, with some pools as large as $20 \mathrm{~m}$ in diameter.

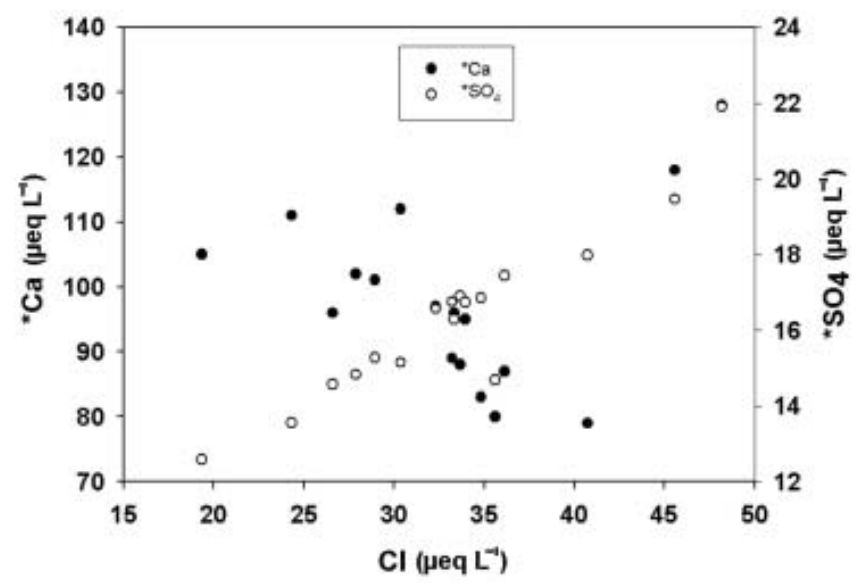

Fig. 3. Scatter plot of ${ }^{*} \mathrm{Ca}^{2+}$ and $* \mathrm{SO}_{4}{ }^{2-}$ vs $\mathrm{Cl}^{-}$for runoff from the main outflow from Canada Glacier during January 2000.

Meltwater is mainly generated from the vertical walls of this surface topography and from the cliffs along the glacier margin, when air temperatures approach $0^{\circ} \mathrm{C}$ (Lewis and others, 1998). Otherwise, subsurface melt occurs as a result of the solar heating of debris in cryoconite holes, channels and pools of varying sizes. Meltwater generation is episodic from day to day, with many cycles of melt-freezing.

\section{METHODOLOGY}

Runoff at the main outlet, which flows into Lake Hoare (Fig. 1), originated from the major pool-riffle system on the southwestern sector of the glacier, and was sampled at $\sim 1000 \mathrm{~h}$ from 16 to 30 January (day of year 16-30) 2000. On several days, a second sample was collected at $\sim 1700 \mathrm{~h}$. Water flowed through an ice-topped channel to the west of Lake Hoare. Discharge was seldom more than a few $\mathrm{Ls}^{-1}$, and fell to a few $\mathrm{mL} \mathrm{s}^{-1}$ during the 2 days of freeze-up on 28 and 30 January. Additional samples were collected from another transect of this major pool-riffle sequence on three occasions, 15, 20 and 30 January. An additional transect was collected along a smaller, so-called 'clean', ice valley complex on the southeastern side of the glacier, adjacent to Lake Fryxell (Fig. 1), on 27 January. Finally, waters were sampled from a transect of the two major pool-riffle systems on Taylor Glacier (Fig. 1) for comparative purposes on 13 and 14 January. During the collection of samples on all transects, the ice top to the channels was pierced by an ice corer and $\sim 500 \mathrm{~mL}$ of sample collected, either directly in a pre-cleaned bottle or via a plastic tube leading into a conical flask under vacuum. All apparatus was rinsed three times with stream water prior to the collection of the main sample. Water samples were immediately filtered following

Table 1. The mean composition of glacier ice and waters within cryoconite holes on Canada Glacier (after Tranter and others, 2004), in comparison with runoff from the main outflow

\begin{tabular}{|c|c|c|c|c|c|c|c|}
\hline & $\mathrm{Cl}^{-}$ & $* \mathrm{Ca}^{2+}$ & DIC & $* \mathrm{SO}_{4}{ }^{2-}$ & $* \mathrm{Mg}^{2+}$ & ${ }^{*} \mathrm{~K}^{+}$ & $* \mathrm{Na}^{+}$ \\
\hline Mean glacier ice & 32 & 36 & 35 & 7.8 & 0.4 & 2.4 & -3.1 \\
\hline Canada Glacier outflow & $19-46$ & $79-130$ & $66-100$ & $14-22$ & $3.0-4.0$ & $2.0-4.0$ & -7.0 to -4.0 \\
\hline Mean Cryoconite holes & 106 & 230 & 150 & 63 & -1.1 & 7.6 & -20 \\
\hline
\end{tabular}



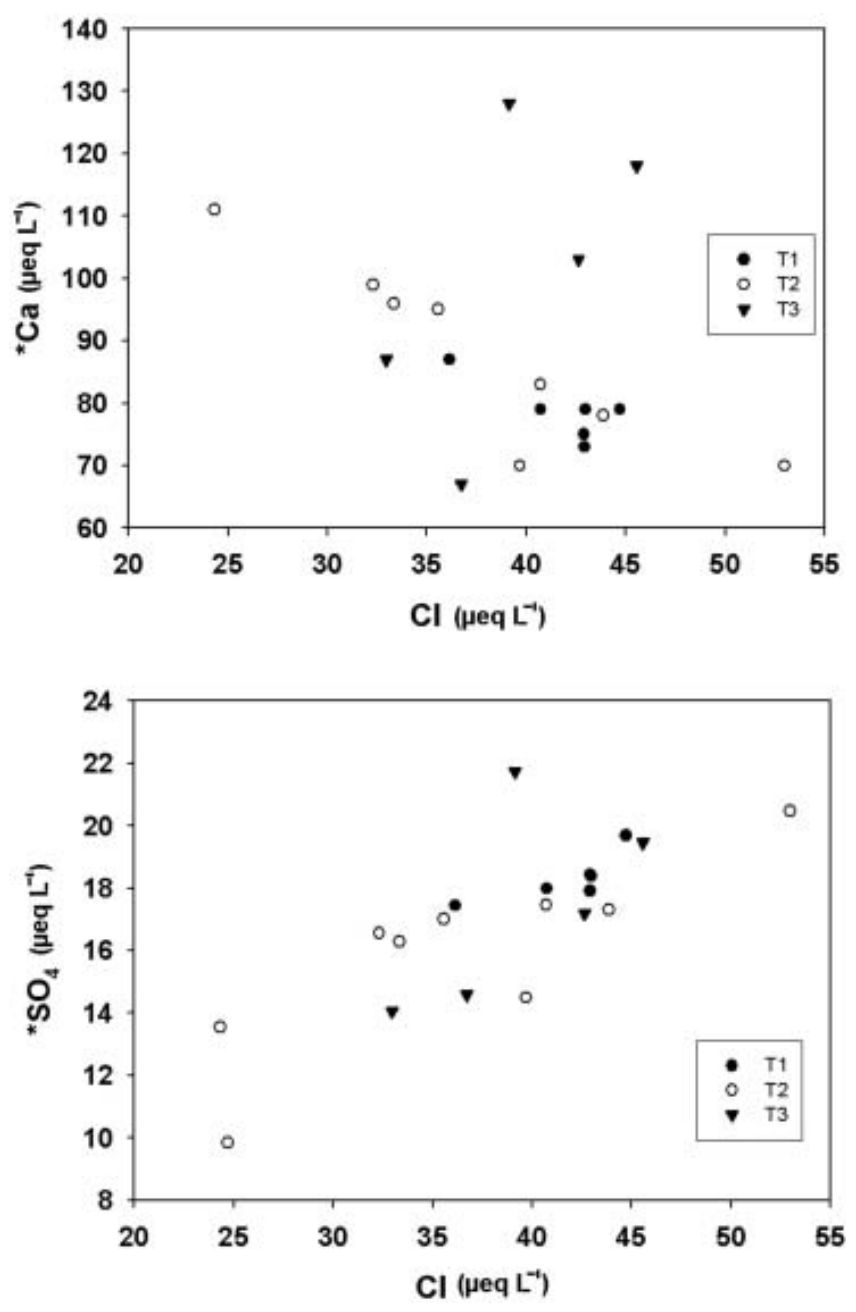

Fig. 4. Scatter plots of $* \mathrm{Ca}^{2+}$ and $* \mathrm{SO}_{4}{ }^{2-} \mathrm{vs}^{-}$for subsurface runoff collected along three transects (T1-T3) of the major pool-and-riffle system on Canada Glacier during January 2000.

collection through $0.4 \mu \mathrm{m}$ Nucleopore membranes, and stored in pre-cleaned polyethylene bottles. Base cations $\left(\mathrm{Ca}^{2+}, \mathrm{Mg}^{2+}, \mathrm{Na}^{+}\right.$and $\left.\mathrm{K}^{+}\right)$and strong acid anions $\left(\mathrm{SO}_{4}{ }^{2-}\right.$ and $\mathrm{Cl}^{-}$) were measured by ion chromatography, and $\mathrm{NH}_{4}{ }^{+}$and $\mathrm{NO}_{3}{ }^{-}$were measured by autoanalyzer. $\mathrm{pH}$ was measured on filtered samples on return to the field laboratory up to 5 hours later. Full details of analytical methods may be found elsewhere (Priscu J.C. and Wolf C.F. 1999. Limnological methods for the McMurdo Long Term Ecological Research Program. Unpublished technical report available from: http://www.homepage.montana.edu/ Ikbonney/DOCS/ Data.html; Tranter and others, 2004). All measurements were conducted within 3 weeks of sample collection at the Crary Laboratory, McMurdo, Antarctica. Dissolved inorganic carbon (DIC) was derived from the charge balance deficit (i.e. the sum of measured positive equivalents minus the sum of measured negative equivalents).

\section{RESULTS}

Figure 2 shows that the chemical composition of runoff from the main Canada Glacier outlet is dominated by sea salt $\left(\mathrm{Na}^{+}\right.$and $\left.\mathrm{Cl}^{-}\right)$and non-sea salt $\left({ }^{*} \mathrm{Ca}^{2+}\right.$ and $\left.\mathrm{HCO}_{3}{ }^{-}\right)$. The range in the concentrations of major ions in runoff is presented in Table 1, along with the mean concentrations in glacier ice and in waters within cryoconite holes for

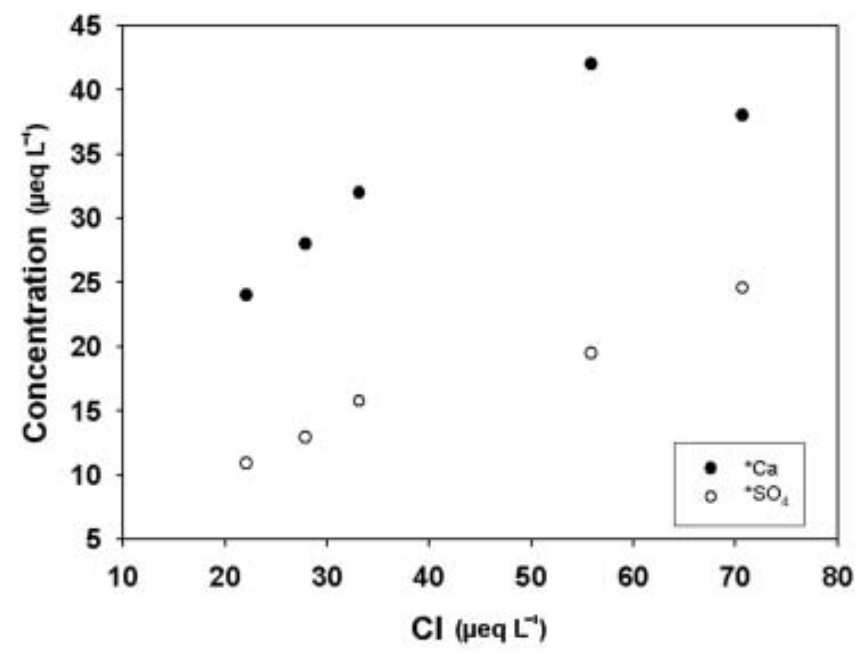

Fig. 5. Scatter plot of ${ }^{*} \mathrm{Ca}^{2+}$ and $* \mathrm{SO}_{4}{ }^{2-} \mathrm{vs} \mathrm{Cl}^{-}$for subsurface runoff collected along a transect of a relatively clean valley on Canada Glacier during January 2000.

comparison. There may be another source of $\mathrm{Cl}^{-}$in the Dry Valleys in addition to sea salt, since ${ }^{*} \mathrm{Na}^{+}$concentrations are negative. Sea-salt concentrations in runoff are $\sim 60-140 \%$ that of mean glacier ice. The waters become depleted in sea salt and ${ }^{*} \mathrm{SO}_{4}{ }^{2-}$ as the hydrological system and melting ice are flushed of solutes from 16 through 27 January. Only during the 2 days of freeze-up (28 and 30 January) does sea salt and $* \mathrm{SO}_{4}{ }^{2-}$ increase in concentration. By contrast, ${ }^{*} \mathrm{Ca}^{2+}$ and $\mathrm{HCO}_{3}{ }^{-}$increase. These ions come from chemical weathering of dust, as confirmed by laboratory dissolution experiments (Fortner and others, in press). Hence, there is an apparent inverse association between ${ }^{*} \mathrm{Ca}^{2+}$ and sea salt (Fig. 3). Only during the two periods of freeze-up do these ions increase simultaneously.

Results from the three transects of the main pool-andriffle system show contrasting features. The first and second transects were sampled when there was noticeable discharge at the main outlet, while the third was sampled between days of freeze-up. The first two transects exhibit a crude increase in ${ }^{*} \mathrm{Ca}^{2+}$ downstream, and a dilution of both sea salt and $* \mathrm{SO}_{4}{ }^{2-}$. This behaviour is in marked contrast to the concentrations measured in waters sampled from the transect of the main pool-and-riffle system during freeze-up, when concentrations of sea salt and ${ }^{*} \mathrm{Ca}^{2+}$ co-vary (Fig. 4), in a similar manner to that observed at the main outflow (Fig. 2).

Results from the transect of the clean valley show a crude decrease in both sea salt and ${ }^{*} \mathrm{Ca}^{2+}$ down-valley. Concentrations of ${ }^{*} \mathrm{Ca}^{2+}$ are $2-5$ times less than in the outlet valley, showing the impact of the dust on the water chemistry. The main subsurface stream on Taylor Glacier exhibits similar features to the clean valley on Canada Glacier, in that sea salt and ${ }^{*} \mathrm{Ca}^{2+}$ are positively associated and crudely decrease downstream. Most of the waters are deficient in ${ }^{*} \mathrm{Ca}^{2+}$ with respect to sea salt when compared with the main outlet on Canada Glacier (Fig. 5).

\section{DISCUSSION}

The main drainage routes on the glacier were largely subsurface, consisting of channels beneath approximately $10-30 \mathrm{~cm}$ of ice. Little melt was produced over the surface 

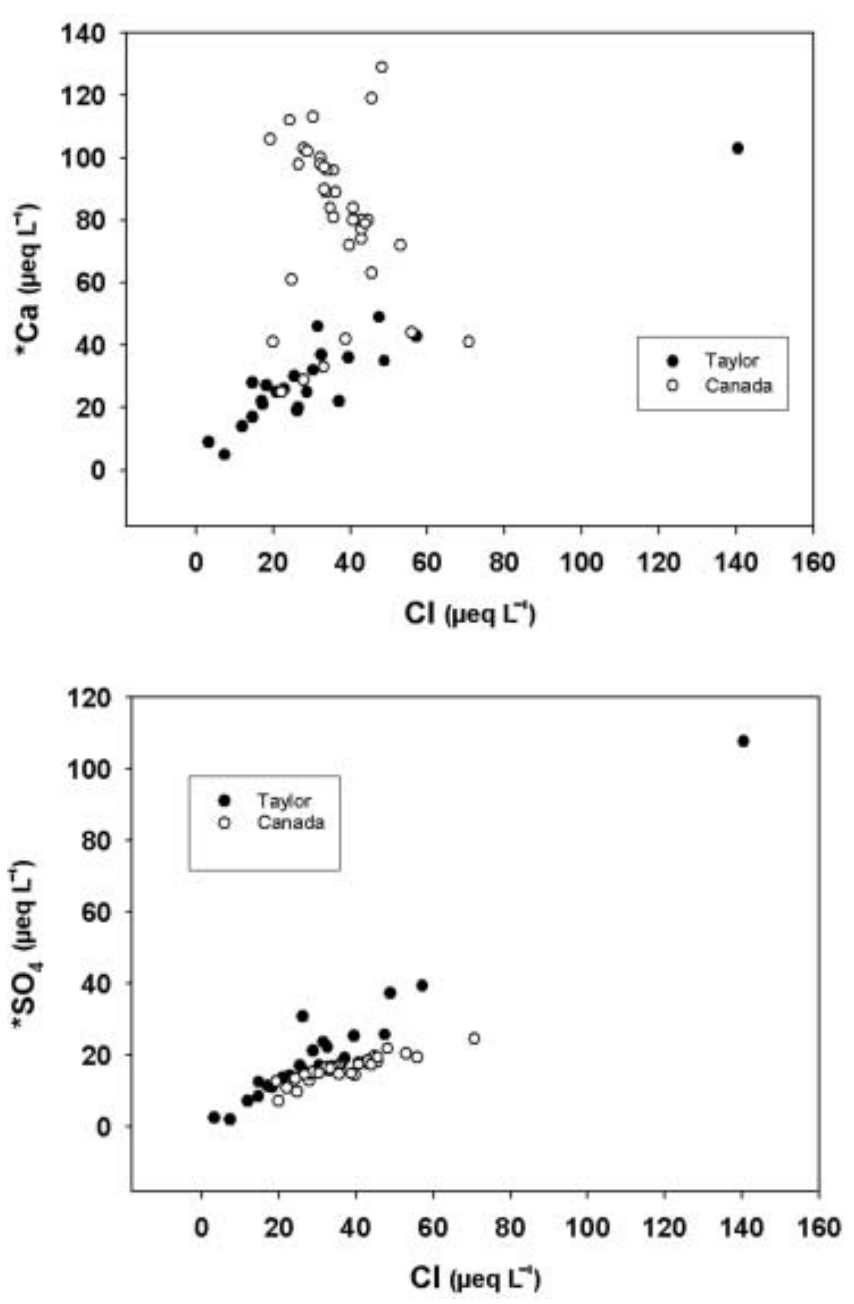

Fig. 6. Scatter plots of $* \mathrm{Ca}^{2+}$ and $* \mathrm{SO}_{4}{ }^{2-} \mathrm{vs} \mathrm{Cl}^{-}$for subsurface runoff collected along two transects of the major pool-and-riffle system on Taylor Glacier and all samples collected from Canada Glacier during January 2000.

of the ablation zone during the sampling period. Much of the water was sourced from internal melting of the surface ice, particularly from debris which was solar-heated. Melting promoted by solar-heated debris occurs within both hydrologically connected and disconnected cryoconite holes, channel beds and large, frozen-over pools. Major subsurface channels develop preferentially along the base of the major pool-and-riffle sequence, and smaller flow paths connect $\sim 50 \%$ of the cryoconite holes which occupy $1-3 \%$ of the surface of the upper, flatter ablation zone (Fountain and others, 2003). These connected cryoconite holes may produce up to $20 \%$ of the runoff from Canada Glacier, and their connection to the major channels is most likely to be via subsurface fissures (Fountain and others, 2003). The cryoconite holes deliver a supply of relatively solute-rich water to the subsurface drainage system (Table 1), and help explain why waters near the top of the major pool-and-riffle system are relatively solute-rich.

Ice melt from the terminus cliffs may contribute up to $20 \%$ of runoff (Lewis and others, 1999). Ice cliffs along the main channels, particularly in the vicinity of the terminus, are also likely to contribute significant quantities of runoff. Continual leaching of solute from the cliff ice during the ablation season is likely to deplete the ice melt of solute, and hence the more solute-rich meltwaters from further up the glacier are diluted at the glacier terminus. Water from the cliffs seeps into the subsurface drainage system via rotten ice at the base of the cliffs. This source of water is sensitive to incoming solar radiation, and is minimal during cold spells when there is freeze-up of the glacier surface. By contrast, water may continue to be produced in the subsurface via solar-heated debris in the pools and channels, and the drainage of connected cryoconite holes. Hence, the increase in ion concentrations during freeze-up arises from both the lack of dilution by ice-cliff melt and the concentration of ions that occurs when water is partially frozen, since ions are preferentially rejected from growing ice crystals and remain in solution (Killawee and others, 1998). This tends to suggest greater input of dilute water down the valley, most likely from the vertical walls of the cliffs along the pool-andriffle sequences, and/or that the ice becomes progressively leached down the valley.

The increase in ${ }^{*} \mathrm{Ca}^{2+}$ and $\mathrm{HCO}_{3}{ }^{-}$downstream is likely to be a function of the decreasing discharge of water during January and the increased residence time of water in debrisbottomed pools en route to the outlet, which gives rise to greater concentrations of ions from dust dissolution. Hence, the increase in dissolution downstream as a result of the increased residence time of the water in contact with debris is sufficient to offset the dilution by ice melt from vertical surfaces. A similar argument can be made to explain the inverse association between ${ }^{*} \mathrm{Ca}^{2+}$ and $\mathrm{Cl}^{-}$in runoff from the main outflow (Fig. 3). The progressive decline in $\mathrm{Cl}^{-}$until day of year 26 (Fig. 2) is most likely the consequence of progressive wash-out of sea salt from the glacier, rather than variable dilution of two fixed end-members from the upper glacier and the ice cliffs. The progressive increase in ${ }^{*} \mathrm{Ca}^{2+}$, which is sourced from dissolution of debris, can then be explained by the increased residence times of water in the subsurface drainage system. This may be the consequence of the receipt of solar radiation decreasing throughout January, so decreasing the amount of meltwater and water flow.

The relatively linear association of the ions in the transects of the major pool-and-riffle sequences on both Canada and Taylor Glaciers (Figs 4-6) suggests that there is mixing of waters en route to the glacier terminus, and that the subsurface drainage system is relatively efficient. The exception is when there is freeze-up of the system, during transect 3 , when the association between ${ }^{*} \mathrm{Ca}^{2+}$ and $\mathrm{Cl}^{-}$is more scattered. This perhaps indicates that the pools are becoming disconnected rather than exchanging and mixing waters down-valley.

The impact of debris as a source of ${ }^{*} \mathrm{Ca}^{2+}$ is best illustrated by reference to ${ }^{*} \mathrm{Ca}^{2+}$ concentrations in the clean-valley transect on Canada Glacier (Fig. 5), which are a factor of $\sim 2-3$ lower than those found in the transect of the more debris-rich major pool-and-riffle system. Further, Taylor Glacier (Fig. 1) does not receive as high a windblown debris loading as Canada Glacier (Porazinska and others, 2004), and concentrations of ${ }^{*} \mathrm{Ca}^{2+}$ are comparable to those of the clean valley on Canada Glacier for a given $\mathrm{Cl}^{-}$ concentration, but are much depleted in comparison to the major pool-and-riffle system (Fig. 6).

\section{CONCLUSIONS}

The hydrochemical processes which occur in the vestigial, subsurface drainage system on Canada Glacier are the elution of ions from ice melt, dilution of these ions 
downstream by ice melt from vertical surfaces and the dissolution of dust, in subsurface pools, channels and/or cryoconite holes. Concentrations of sea salt are highest at the top of the major pool-and-riffle system on Canada Glacier, and decrease downstream due to dilution by ice melt from vertical surfaces, particularly in the region of the terminus. By contrast, ${ }^{*} \mathrm{Ca}^{2+}$ concentrations increase due to debris dissolution. Sea-salt concentrations decrease over time at the main outlet due to progressive wash-out of seasalt aerosol from the glacier drainage system. Again by contrast, ${ }^{*} \mathrm{Ca}^{2+}$ concentrations increase over time due to the prolonged residence time of waters in the drainage system en route to the outlet.

\section{REFERENCES}

Doran, P.T. and 12 others. 2002a. Antarctic climate cooling and terrestrial ecosystem response. Nature, 415(6871), 517-520.

Doran, P.T. and 6 others. 2002b. Valley floor climate observations from the McMurdo Dry Valleys, Antarctica, 1986-2000. J. Geophys. Res., 107(D24), 4772. (10.1029/2001JD002045.)

Fortner, S.K., M. Tranter, A.G. Fountain, W.B. Lyons and K.A. Welch. In press. The geochemistry of supraglacial waters and their evolution in proglacial waters, Canada Glacier, Taylor Valley, Antarctica. Aquatic Chemistry.

Fountain, A.G., G.L. Dana, K.J. Lewis, B.H. Vaughn and D.M. McKnight. 1998. Glaciers of the McMurdo Dry Valleys, southern Victoria Land, Antarctica. In Priscu, J.C., ed. Ecosystem dynamics in a polar desert: the McMurdo Dry Valleys, Antarctica. Washington, DC, American Geophysical Union, 65-75. (Antarctic Research Series 72.)

Fountain, A.G. and 12 others. 1999. Physical controls on the Taylor Valley ecosystem, Antarctica. BioScience, 49(12), 961-971.

Fountain, A.G., M. Tranter, T.H. Nylen, K.J. Lewis and D. Mueller. 2003. Evolution of cryoconite holes and their contribution to meltwater runoff from glaciers in the McMurdo Dry Valleys, Antarctica. J. Glaciol., 50(168), 35-45.

Hodgkins, R., M. Tranter and J.A. Dowdeswell. 1998. The hydrochemistry of runoff from a 'cold-based' glacier in the High Arctic (Scott Turnerbreen, Svalbard). Hydrol. Processes, 12(1), 87-104.

Killawee, J.A., I.J. Fairchild, J.L. Tison, L. Janssens and R. Lorrain. 1998. Segregation of solutes and gases in experimental freezing of dilute solutions: implications for natural glacial systems. Geochim. Cosmochim. Acta, 62(23-24), 3637-3655.

Lewis, K.J., A.G. Fountain and G.L. Dana. 1998. Surface energy balance and meltwater production for a Dry Valley glacier, Taylor Valley, Antarctica. Ann. Glaciol., 27, 603-609.

Lewis, K.J., A.G. Fountain and G.L. Dana. 1999. How important is terminus cliff melt?: a study of the Canada Glacier terminus, Taylor Valley, Antarctica. Global Planet. Change, 22(1-4), 105-115.

McKnight, D.M., D.K. Niyogi, A.S. Alger, A. Bomblies, P.A. Conovitz and C.M. Tate. 1999. Dry valley streams in Antarctica: ecosystems waiting for water. BioScience, 49(12), 985-995.

Moorhead, D.L. and 7 others. 1999. Ecological legacies: impacts on ecosystems of the McMurdo Dry Valleys. BioScience, 49(12), 1009-1019.

Nylen, T.H., A.G. Fountain and P.T. Doran. 2004. Climatology of katabatic winds in the McMurdo Dry Valleys, southern Victoria Land, Antarctica. J. Geophys. Res., 109(D3)D03114. (10.1029/ 2003JD003937.)

Porazinska, D.L., A.G. Fountain, T.H. Nylen, M. Tranter, R.A. Virginia and D.H. Wall. 2004. The biodiversity and biogeochemistry of cryoconite holes from McMurdo Dry Valley glaciers, Antarctica. Arct. Antarct. Alp. Res., 36(1), 84-91.

Priscu, J.C., ed. 1998. Ecosystem dynamics in a polar desert: the McMurdo Dry Valleys, Antarctica. Washington, DC, American Geophysical Union, 65-75. (Antarctic Research Series 72.)

Tranter, M. and 6 others. 2004. Extreme hydrochemical conditions in natural microcosms entombed within Antarctic ice. Hydrol. Process., 18(2), 379-387. 